\title{
D 102
}

\section{「成人病予防教室の奻果」第 1 報 〜脂質改善における教室の意義〜}

\author{
○徳永朋子小林明美 森綾子 前田 奈留美 今城好恵 藤原 采 \\ 西田真由美 斉藤 久美 高橋雅子桑野綾 佐藤 可絵藤井恭子 \\ 栢菅昇 下村董 吉田 智郎（日本鋼管福山病院 健康管理科）
}

【はじめに】生活習慣の変化に伴い血清脂質異常者は 年々增加傾向にある。これは動脈硬化性疾患の発症に 深く関与しており、予防対策はかかせない。現在、主 に食事や生活習慣の是正を目的とした個別指導を中 心に動脈硬化性疾患の予防活動を行っている。1 年間 の途中経過をまとめた結果と、教室の意義・効果につ いて検討したので報告する。

【対象と方法】1995 年の健康診断で、動脈硬化指数 (AI) 5.5 以上の 170 (当所男性従業員)名の内、「成人病 予防教室」に参加申込みがあり、かつ 1996 年 8 月〜 1997 年 8 月の間に追跡可能であった 100 名(たたし、 菜物治療者は除く）を対象とした。又、未参加者（薬 物治療者を除く 19 名) を比較刘照群とした。参加者 全員に万歩計を配布し、歩数・喫煙数・飲酒量等の生 活習慣を日々「ライス多价ェ师表」に記入する事を義務 ゔけた。 1 年間で集団教育 3 回、検査（血液: TCH・ $\mathrm{HDL}-\mathrm{C} \cdot \mathrm{TG}$ 計測: 体重・体脂肪率) 6 回、個別指導 8 回、試食会 1 回を実施した(表 1 )。

【結果及び考察】検查項目別に、全体をみると特に目 立つのか、 $\mathrm{AI}$ が開始時 $5.4 \pm 1.3$ から 1 年後に $4.5 \pm$ 1.0 へと有意に改善しており、TG 以外の $\mathrm{TCH}$ HDL-C・肥满度にも有意な改善を認めた(表 2)。これ は、動機づけとして対象者には生活習慣を見直す目的 で、援助者は努力状況を確認する手段として半年間で はあるか、「ライフス价化师表」を活用したことが理由の 1つと考えられる。

全体の年間推移をみると半年間は有意な改善がみ られ、1 年後はほぼ横ばいである(表 2)。検査後に、 事前配布したアクケート類の分析結果とともに結果説明を 行い、次回検查までの具体的で実行可能な改善目標と 具体策をともに考える面談形式を 1 年間繰り返した ことが、改善につながり、リバウバを防ぐのにも有効 的だったと考えられる。

年代別にみると、各年代とも AI が有意に改善して いる。その他は 30 代では HDL-C が、40 代では TG 以外の全ての項目に有意な改善を認めた(表 2)。特に 40 代に有意な改善を認めたのは、この頃から自分の 健康に関心を持ちはじめるためと思われる。

対照群をみると有意な改善は認められないが、教室 参加者は多くの検查項目において有意に改善してい る(表 2)。これは、検查と並行した自己の生活習慣を振
り返るための面談を繰り返し行った成果と考えられ る。そして、これらの関わりは成人病予防の一助にな ると推測される。

【まとめ】これまで、集団教育による成人病予防に対 する情報(知識) 提供は行ってきたが、1 年間に及ふ個 別指導を中心とした継続的な関わりは初の試みであ った。今回、有意な改善か認められたのは対象者自身 が生活習慣を見直すために記録表(「ライ亿ス价チェック表」) を活用したことや集団教育のみによる単なる情報提 供にとどまらず、アリクート類や検查結果の分析を援助者 側が十分に行ったうえで指導に臨んたここと、また対象 者と援助者がそれらの分析をもとに、具体的で実行可 能な改善目標と具体策をともに考える面談形式をと った成果であると考えられる。この様なかかわりが川 バウトドを防ぐのに有効的であると考える。今後も検査 と並行して繰り返しの面談を行い、行動変容につなか るような情報提供を対象者の理解度を確認しながら 集団い゙ルにとどまることなく、さらに進んで個人川゙ ルで継続していける環境を提供していくことか「成人 病予防」対策にとって重要になると考えられる。その ためには、長期的な教室運営が必要であり、今回の対 象者へは、これからも予防活動を継続する予定である。

表 1 教室の年間突施内容

\begin{tabular}{|c|c|c|c|c|c|c|c|c|c|}
\hline 96.8 & 9 & $10]$ & $1] 1$ & 297.1 & 2 & 3 & 5 & 7 & $\overline{8}$ \\
\hline 開笨式 & & & & & 閉讙式 & 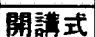 & & & \\
\hline 售 話 & & & & & () & (2) & (2) & & \\
\hline 検査 & & C & (9) & & (2) & (2) & (2) & & (2) \\
\hline & 固別指望 & 0 & a) & & (2) & (2) & (2) & & (a) \\
\hline$\overline{7 ン ケ-ト ~}$ & & (2) & (c) & & & & (2) & () & \\
\hline \multicolumn{5}{|c|}{ ヒ「ライフスタイルチ } & & & 試食会 & & \\
\hline
\end{tabular}

○は目模達成率の低かった者のみ26名に実施

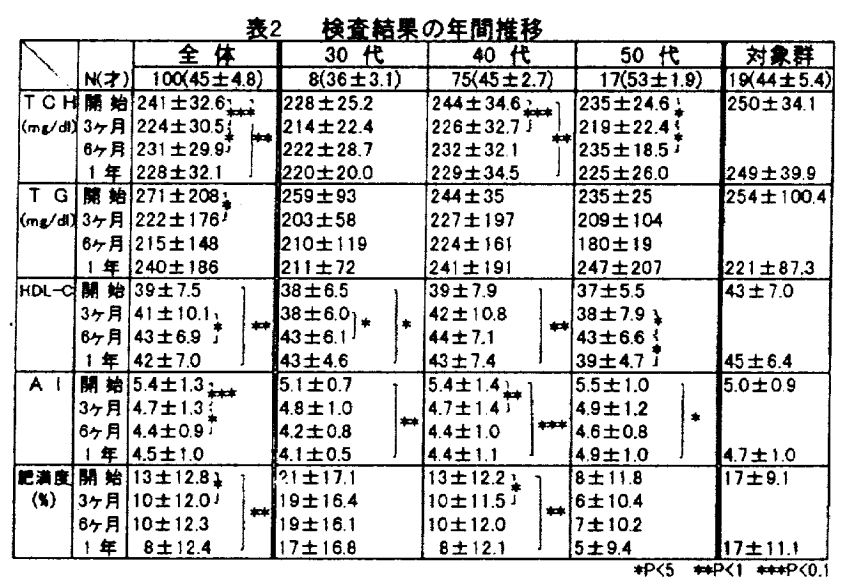

